\title{
希な受傷機転で発症したと思われる 化膿性肩関節炎の治療経験
}

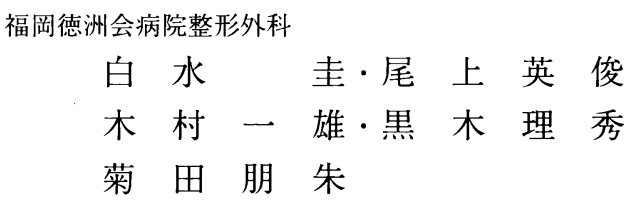

\section{A Case Report of an Uncharacteristic Onset of Purulent Arthritis of the Shoulder}

\author{
Kei Shiramizu, Hidetoshi Onoue, Kazuo Kimura, \\ Yoshihide Kuroki, and Tomomi Kikuta \\ Department of Orthopaedic Surgery, \\ Fukuoka Tokushukai Hospital
}

\begin{abstract}
This report describes purulent arthritis of the shoulder with an uncharacteristic onset and discussion about the etiology of purulent arthritis.

A 48 year old female suffered from chronic left shoulder pain and therefore underwent an old wives remedy (bee therapy) at the end of 2000 . After the therapy, she noticed mild shoulder warmth and pain. 4 weeks after the therapy the warmth and pain increased rapidly, prompting her to consult our clinic. On physical examination, local heat and swelling were recognized on her left shoulder, and she could not move her shoulder because of her severe pain. Physical and labolatory findings were consistent with purulent arthritis. We executed irrigation and de'bridement of her left shoulder after the diagnosis of purulent arthritis of the shoulder.
\end{abstract}

Key words : purulent arthritis (化膿性関節炎), shoulder joint（肩関節）, bee therapy（ミツ バチ療法)

はじめに

化膿性肩関節炎の発症頻度は人口の高齢化に伴い近 年増加傾向にある. 今回, 比較的希な受傷機転で発症 したと考えられる化膿性肩関節炎を経験したので報告 する。

症例

48 歳女性, 主婦.

主訴: 左肩痛.

病歴：平成 12 年 12 月末に肩こりに対しての民間療法 として，みつばちによる蜂刺療法を受けた，以後，肩
関節痛, 腫脹, 軽度の熱感を自覚していたが, 症状が 増悪してきたため平成 13 年 1 月 29 日に当科を受診し

た。

既往歴 : 特記すべき事項なし.

理学所見: 肩関節局所の高度な熱感, 発赤, 腫脹を認 め前方には波動を触知し, 関節穿刺で黄白色の嶈液性 穿刺液を約 $3 \mathrm{cc}$ 吸引できた。肩関節の自・他動運動 は疼痛が強くほとんど不可能であった。

血液検査所見：血液検査では, CRP $2.9 \mathrm{mg} / \mathrm{dl}$, WBC $16,100 / \mathrm{mm}^{3}$, 血沈1時間值 $22 \mathrm{~mm}, 2$ 時間値 $62 \mathrm{~mm}$ と高値を示したが, 他の生化学検査項目では 特に異常所見は認めなかった。 
画像所見：単純X線写真では特に異常所見を認めなかっ たが，MRI（T2）所見で肩峰下滑液包と肩甲上腕関 節に high intensity areaを認め, 膿の貯留が示唆 された（図 1-4）.

以上より，化膿性肩関節と診断し翌日に手術を施行 した.

手術所見：Deltopectoral incisionにて関節を展開 した，肩峰下滑液包，肩関節包とも漿液性の黄白色の 膿が貯留し腫脹していた。肩峰下滑液包は切除し，関 節包を関節窩の外側で縦に切開すると axillary pouchの部分には滑膜の増殖を認めたが，関節軟骨 には特に異常を認めなかった。滑膜切除を行い，パル ス洗浄器を使い生食 101 で十分に洗浄を行いドレーン
を留置し，関節包を縫合し創を閉鎖した。

術後経過: 1 月 30 日の手術後よりセフメタゾール $1 \mathrm{~g}$ を 1 日 3 回静注, ゲンタマイシン $60 \mathrm{mg}$ を 1 日 2 回 筋注とし，2月 6 日よりセフジニル $100 \mathrm{mg}$ を 1 日 3 回の内服のみに切り替えた。2月16日の退院時には 炎症所見も落ち着き抗生剂はすべて終了とした. 初診 時の関節穿刺液からは菌は検出されなかったが, 手術 時の関節液培養から表皮ブドウ球菌が検出された。摘 出した滑膜組織の病理診断は化膿性関節炎であった. 肩関節の可動域は術後 2 ケ月でほぼ制限を認めなくな り，日常生活動作においても支障とならないレベルま で回復した（表 1 ).

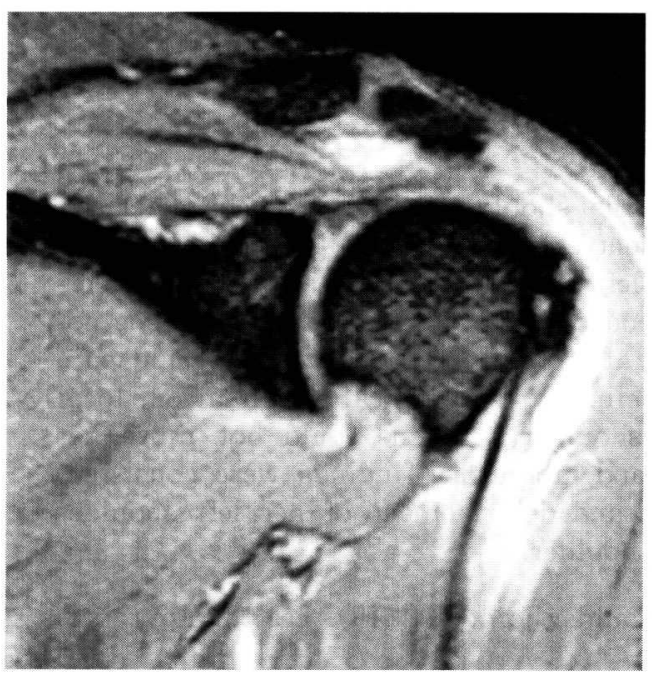

図 1

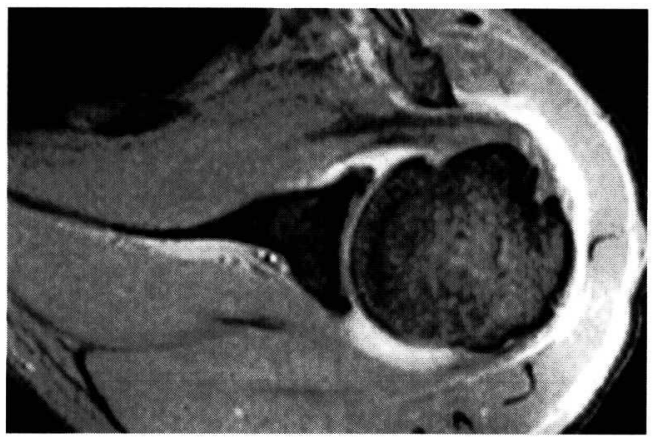

図 3

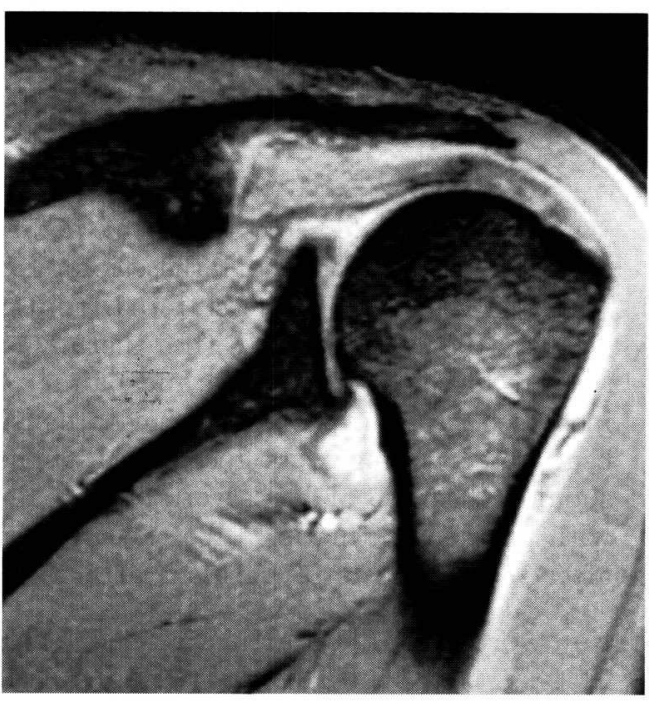

図 2

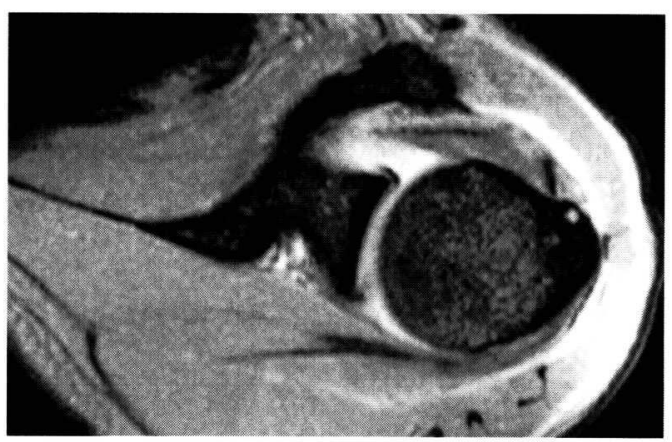

図 4

図 1-4 MRI (T2) 所見

肩峰下滑液包と肩甲上腕関節に膿貯留を示唆する high intensity area を認めた。 
表 1 術後経過

術後約 2 週間で炎症所見は落ち着き, 術後約 2 ケ月で関節可動域の回復を認めた。

\begin{tabular}{|c|c|c|c|c|c|c|c|c|c|}
\hline & $1 / 29$ & $\begin{array}{c}1 / 30 \\
\text { 手術日 }\end{array}$ & $1 / 31$ & $2 / 6$ & $2 / 7$ & $2 / 13$ & $\begin{array}{c}2 / 16 \\
\text { 退院日 }\end{array}$ & $3 / 1$ & $3 / 29$ \\
\hline WBC $\left(/ \mathrm{mm}^{3}\right)$ & 16100 & 9600 & 10700 & 8500 & 11000 & 10300 & 10300 & 8900 & \\
\hline $\mathrm{CRP}(\mathrm{mg} / \mathrm{dl})$ & 2.9 & 4.4 & 2.9 & 0.6 & 0.5 & 0.3 & 0.3 & 0.5 & \\
\hline $\operatorname{ESR}(1 \mathrm{~h} / 2 \mathrm{hmm})$ & $22 / 62$ & & $36 / 75$ & $25 / 63$ & $45 / 94$ & $35 / 35$ & $30 / 60$ & $31 / 65$ & \\
\hline BT $\left({ }^{\circ} \mathrm{C}\right)$ & 37.5 & 37 & 37.2 & 36.8 & 36.8 & 36.8 & 36.3 & 36.7 & \\
\hline shoulder flex. & & & & & & 45 & 50 & 90 & 170 \\
\hline shoulder abd. & & & & & & 45 & 50 & 90 & 170 \\
\hline 抗生剂 & & & CMZ, & $\mathrm{M} \rightarrow \mathrm{CF}$ & $\rightarrow$ 中止 & & & & \\
\hline
\end{tabular}

考察

化膿性肩関節炎発症の素因について人口の高齢化に 伴う免疫力の低下, 糖尿病, 尿路感染症等の基礎疾患 があげられている，原因について欧米の報告例では血 行性感染が多いのに対して, 本邦では肩関節の関節内 注射，局所注射などによる医原性感染例が多い(13/15).

蜂刺療法は多数のミッバチを肩関節周辺に放ち, 刺 させるという内容であり，化膿性肩関節炎発症までの 関連性を考察した. 蜂刺し直後より局所の発赤, 腫脹, 疼痛は出現しているが，化膿性関節炎の発症までには 約 1 ケ月を要している。この 1 ケ月は皮虙の常在菌で ある表皮ブドウ球菌による炎症が蜂刺しの刺激で，ま ず表面におこり徐々に深部へ広がり，最終的に関節内 まで波及するのに要した期間であると考えられる。さ らに, 今回の症例は 48 歳と比較的若年で特に基礎疾 患はなく，肩関節への注射などの既往がないことより， 受傷機転は蜂刺し療法によるものではないかと考えら れた。

ミッバチの毒性について, 文献的には臨床症状とし て認められるのは蜂毒の薬理作用とそれに対するアレ ルギー反応であった，蜂毒としてはヒスタミン，七ロ トニン, キニン, アセチルコリン等が挙げられてい $3^{4) 6-8)}$. 皮唐常在菌である表皮ブドウ球菌は弱毒菌で ある。感染源となる場合は長期に及ぶ IVH 等の留置 カテーテルから血行性に感染するケースがほとんどで, 皮膚からの直接感染は稀であるとされる ${ }^{2}$. 今回のケー スの様に刺される部位が限局した範囲でかつ多数にな るとアレルギー症状のみではなく常在菌による皮庯か らの直接感染の可能性も高くなるのではないかと思わ
れる. 昭和 29 年に報告された文献にはミツバチの蜂 毒を用いた蜂刺療法が皮膚，関節における疼痛性疾患 に有効であるとの記載もあっだ"．現在でもこのよう な民間療法は一部で行われており発症原因がはっきり しない時は, 注意深く病歴を聴取することが必要であ ると思われる。

\section{ま と め}

受傷機転が希であると思われる化膿性肩関節炎を経 験したので報告した。診断に際しては年齢，基礎疾患 の有無に関わらず，注意深く病歴を聴取し疑いがあれ ば早期に加療を行うことが重要であると考えられた。

\section{参 考 文 献}

1）福島一雅ら：肩関節感染症に対する関節鏡視下 de'bridement による治療経験。肩関節， 16(1) : 1-4, 1992.

2) Gordon, L. A. et al.: Staphylococcus Epidermidis And Other Coagulase-Negative Staphylococci, Principles And Practice Of Infectious Disease Third Edition, 1511-1516, Gerald L. Mandell, New York, Churchill Livingstone, 1990.

3）嘉村親芳ら：化膿性肩関節炎の臨床像および治療成績. 肩関節, 12(2) : 259-263, 1988.

4）北村包彦ら：日本皮庙科全書．10(1)，306，金原四郎， 東京, 金原出版, 1954 .

5）宗圆 聰：非リウマチ性関節炎，結晶性関節炎。関節 外科, 17(增刊号)：208-211，1998.

6）鈴木啓之ら：皮虐科診断治療大系. Suppl. 2，52-53， 野間佐和子, 東京, 講談社, 1992 .

7）鈴木 猛, 緒方一喜: 日本の衛生害虫一その生態と駆 除一. 8, 199-201, 辻本重雄, 東京, 新思潮社, 1982.

8）山村雄一ら：現代皮席科学大系. 8，266-271, 中山八 郎平, 東京, 中山書店, 1984 . 